\title{
Culturable endophytic Pseudomonas fluorescens Z1B4 isolated from Zanthoxylum alatum Roxb. with stress-tolerance and plant growth-promoting potential
}

\author{
Pratibha Vyas $^{1,2 *}$, RAMANPREet KaUR ${ }^{2}$ \\ ${ }^{1}$ Department of Microbiology, College of Basic Sciences and Humanities, Punjab Agricultural University, Ludhiana, Punjab, India \\ ${ }^{2}$ Microbiology Domain, School of Bioengineering and Biosciences, Lovely Professional University, Phagwara, Punjab, India
}

\begin{abstract}
Endophytes are an important constituent of sustainable agriculture because of their ability to produce a large number of agriculturally important metabolites. A salt-tolerant fluorescent green pigment-producing endophytic bacterium was isolated on 2.5\% NaCl-supplemented nutrient agar from the leaf samples of Zanthoxylum alatum Roxb. The isolate Z1B4 was identified as Pseudomonas fluorescens based on morphological features, fatty acid methyl ester analysis, biochemical tests, and 16S rRNA gene sequencing. $P$. fluorescens Z1B4 showed positive results for tricalcium phosphate solubilization; 1-aminocyclopropane-1-carboxylate (ACC) deaminase activity; and production of auxins, siderophores, hydrogen cyanide, and ammonia. P. fluorescens Z1B4 also showed strong antagonistic activity against Curvularia lunata (MTCC 283), Fusarium verticillioides (MTCC 3322), and Alternaria alternata (MTCC 1362) and exhibited stress tolerance to a wide range of temperature and $\mathrm{pH}$ and concentrations of $\mathrm{NaCl}$ and calcium salts. Under natural conditions, following inoculation with the isolate Z1B4, a significant increase in the growth of pea and maize test plants in pots was observed compared to that of uninoculated control plants. The rifampicin-resistant mutant $\mathrm{Z1B} 4{ }^{\mathrm{Rif}}$ was recovered from the roots, shoots, and leaves of the test plants, indicating that the isolated endophytic bacterium can grow well within different plant tissues. The present study indicated that the endophytic bacterium $P$. fluorescens Z1B4 can be used as a bacterial inoculant in stressed environments for sustainable agriculture.
\end{abstract}

Key words: antagonism, endophytes, fluorescent Pseudomonas, phosphate solubilization, medicinal plants, Northeast India

\section{Introduction}

Sustainable crop production for feeding ever-increasing human population is one of the major challenges for agriculture in the twenty-first century (Vyas and Kaur, 2019). Because of excessive utilization of chemical pesticides and fertilizers, an extensive burden has been imposed on agriculture (Fadiji and Babalola, 2020). Therefore, to reduce the use of chemical fertilizers, safe and efficient alternatives are required to improve productivity and sustainability in agriculture. Endophytic bacteria are an important constituent of sustainable agriculture because of their ability to play an important role in enhancing plant growth and productivity (Pageni et al.,
2014; Vyas and Kaur, 2019). Microorganisms have a vast potential as an alternative to the use of chemical fertilizers and pesticides. Microbial endophytes are known to solubilize insoluble phosphates and produce plant hormones, including auxins, cytokinins, and gibberellins; siderophores; ammonia; hydrogen cyanide; and 1-aminocyclopropane-1-carboxylate (ACC) deaminase (Fadiji and Babalola, 2020). They also help the plants to tolerate different stress conditions and grow better. Different endophytes have shown their association with medicinal plants, including Adhatoda vasica, Curcuma longa, Plectranthus tenuiflorus, Tinospora cordifolia, Picrorhiza kurroa, Phyllostachys edulis, Vernonia anthelmintica,

\footnotetext{
* Corresponding author: Department of Microbiology, College of Basic Sciences and Humanities, Punjab Agricultural University, Ludhiana-141004, Punjab, India; e-mail: vyasp2000@pau.edu
} 
Withania somnifera, and Zingiber officinale (Liu et al., 2017; Vyas, 2018; Vyas and Kaur, 2019; Rustamova et al., 2021). The endophytes associated with the medicinal plants have been identified to belong to species of Alcaligenes, Bacillus, Clavibacter, Curtobacterium, Delftia, Exiguobacterium, Micrococcus, Paenibacillus, Methylobacterium, Microbacterium, Pseudomonas, and Stenotrophomonas (Yuan et al., 2015; Kumar et al., 2016; Vyas, 2018; Vyas and Kaur, 2019). Fluorescent Pseudomonas are the predominant group of bacteria residing in the plant rhizosphere and inside plant tissues as endophytes, and they affect plant growth by enhancing the nutrient status of soil and availability of nutrients to the plants (Gulati et al., 2009). Endophytic Pseudomonas fluorescens that exhibits siderophore production, ACC deaminase activity, and inorganic phosphate solubilization was shown to colonize the roots of Brassica napus and to significantly increase the plant biomass compared to uninoculated control plants (Lally et al., 2017).

Various abiotic and biotic factors influence the performance of beneficial microorganisms and also affect the plant growth (Sharan et al., 2008; Vyas et al., 2010; Kaur et al., 2018; Porter et al., 2020). Most of the beneficial microorganisms that show excellent results in laboratory studies, however, fail to show consistent results in field testing, mainly because of the changing environmental conditions (Gulati et al., 2010; Parnell et al., 2016). Therefore, screening the microorganisms for their ability to tolerate different stresses is an important trait during their selection for the development of bioinoculants for agriculture. Limited literature is available on the screening of stress-tolerant bacterial strains for developing microbial inoculants (Sharan et al., 2008; Vyas et al., 2010; Vyas and Kaur, 2019). One approach for developing microbial inoculants for stressed environments is the selection of bacteria with stress tolerance and multifarious plant growth-promoting traits. The application of such microorganisms can be useful to decrease the consumption of chemicals in stressed ecosystems for sustaining agriculture. Plant growth is also negatively affected by plant pathogens that cause various plant diseases. Plant pathogens including Curvularia lunata and Fusarium species have been known to cause diseases in different families of various plant species (Lal et al., 2013; Ghosh et al., 2016).

Northeast India, a part of the Himalayas, spread between the latitudes $21^{\circ} 34^{\prime} \mathrm{N}$ to $29^{\circ} 50^{\prime} \mathrm{N}$ and longitudes $87^{\circ} 32^{\prime} \mathrm{E}$ to $97^{\circ} 52^{\prime} \mathrm{E}$, supports approximately $50 \%$ of India's biodiversity and is one of the "biodiversity hotspots" of the world (Mao and Hynniewta, 2000; Tripathi et al., 2016; Venkataraman and Sivaperuman, 2018). Many endophytic microorganisms have been reported to produce similar compounds as produced by their host medicinal plants and also help their host plants to tolerate different stress conditions (Lata et al., 2018). For example, taxol or paclitaxel, a diterpenoid compound, used to treat ovarian, breast, and lung cancer was isolated for the first time from Taxus brevifolia and subsequently isolated from endophytes (Stierle et al., 1993). Likewise, compounds with antimicrobial activity, such as methyl ester, 1,2-bezenedicarboxyl acid, decanodioic acid, and bis (2-ethylhexyl) ester, have been isolated from endophytic bacteria Bacillus mojavensis and $\mathrm{Ba}$ cillus atrophaeus isolated from Glycyrrhiza uralensis (Mohamad et al., 2018). Zanthoxylum alatum Roxb., commonly known as tejphal, timur, or timber, is used to treat bronchitis, asthma, cholera, fever, skin diseases, indigestion, and toothache. Leaves of this plant are reported to have hepatoprotective activity (Annappan et al., 2015). To date, plant-growth promoting endophytic bacteria with stress tolerance have not been reported from the medicinal plant $Z$. alatum Roxb. Therefore, the present study aimed to select stress-tolerant plant growth-promoting endophytic bacteria from $Z$. alatum Roxb. for use as a microbial inoculant in stressed environments for sustainable agriculture.

\section{Materials and methods}

\section{Isolation and identification of endophytic bacteria}

Leaf samples of $Z$. alatum Roxb. were collected from the healthy plants growing in Manipur, India $\left(24^{\circ} 48^{\prime} 50.2812^{\prime \prime} \mathrm{N}\right.$ and $\left.93^{\circ} 57^{\prime} 1.0044^{\prime \prime} \mathrm{E}\right)$. The samples were processed by washing with tap water first and then surface sterilized by dipping in ethanol (75\%) for $30 \mathrm{~s}$ followed by immersion in $0.2 \% \mathrm{HgCl}_{2}$ for $3 \mathrm{~min}$ and then washed thrice with sterilized distilled water. The leaves were cut into approximately 1-2 mm sections, placed on nutrient agar (NA) containing $2.5 \% \mathrm{NaCl}$, and incubated in dark at $28^{\circ} \mathrm{C}$ for $24-72 \mathrm{~h}$. An endophytic bacterium showing fluorescent-green pigment growing in the vicinity of leaf sample was purified on NA, designated as Z1B4, and preserved in 30\% glycerol. 


\section{Characterization and identification of $Z 1 B 4$ bacterial strain}

The endophytic bacterial isolate Z1B4 was characterized and identified on the basis of phenotypic characteristics, fatty acid methyl ester (FAME) analysis, and 16S rRNA gene sequencing. Morphological feature analysis, staining, and biochemical tests were performed following Krieg and Holt (1984). FAME analysis was performed by gas chromatography as described earlier (Sasser and Wichman, 1991; Gulati et al., 2008). 16S rRNA gene sequence analysis that included DNA isolation, gene amplification, thermocycling conditions, and sequence analysis was carried out as described by Gulati et al. (2008). The sequences obtained were aligned with Clustal W, and the evolutionary distance of the endophytic bacterium Z1B4 and its related taxa was calculated by MEGA software package version 7 using Kimura's two-parameter model.

\section{Solubilization of inorganic phosphate}

$\mathrm{NaCl}$-tolerant bacterial isolate Z1B4 was qualitatively tested for phosphate solubilization by the plate assay. The bacterial culture was spot inoculated on modified Pikovskaya's agar, and plates were incubated at $28^{\circ} \mathrm{C}$ for 5 days. The clear halo formed due to tricalcium phosphate solubilization around the bacterial colony were measured on the fifth day of incubation. Quantitative estimation was performed in $50 \mathrm{ml}$ sterile National Botanical Research Institute Phosphate (NBRIP) broth inoculated with $100 \mu \mathrm{l}$ of the Z1B4 bacterial culture adjusted to $\mathrm{O}_{\mathrm{D} 630} 1-3 \times 10^{9} \mathrm{CFU} / \mathrm{ml}$ (Nautiyal, 1999). The flasks were incubated in triplicate at $28^{\circ} \mathrm{C}$ at $180 \mathrm{rpm}$ in a shaking incubator, with uninoculated sterile NBRIP broth serving as control. On the fifth day of incubation, the cultures were centrifuged at $10000 \mathrm{rpm}$ for $10 \mathrm{~min}$, and supernatants were collected in sterile test tubes. The amount of soluble phosphorus in the culture supernatant was estimated by the yellow color method (Gulati et al., 2008).

\section{Production of auxins}

Nutrient broth (NB) amended with $0.1 \%$ DL-tryptophan was inoculated with $50 \mu$ of 24-h-old Z1B4 bacterial culture and incubated in dark at $28^{\circ} \mathrm{C}$. After $48 \mathrm{~h}$ incubation, the cultures were centrifuged at $10000 \mathrm{rpm}$ for $10 \mathrm{~min}$, and supernatants were collected. Auxins in the culture supernatants were estimated using Salkowski reagent according to the method of Loper and Schroth (1986). Briefly, $4 \mathrm{ml}$ Salkowski reagent was added to $1 \mathrm{ml}$ supernatant, and the absorbance of the resultant pink color was measured at $535 \mathrm{~nm}$ after $10 \mathrm{~min}$. Uninoculated NB with tryptophan was used as control. The experiment was performed in triplicate.

\section{ACC deaminase activity}

The isolate Z1B4 was streaked on Dworkin and Foster (DF) salt minimal medium with ACC as the sole nitrogen source. The plates were incubated for $48 \mathrm{~h}$ at $28^{\circ} \mathrm{C}$ and observed for the appearance of growth (Glick, 2014).

\section{Siderophore production}

The bacterial culture Z1B4 was spot inoculated on chrome azurol sulphonate (CAS) plates and incubated for 5 days at $28^{\circ} \mathrm{C}$. The size of the orange halo produced was measured (Schwyn and Neilands, 1987). Before the preparation of the medium, the glassware was cleaned with $20 \% \mathrm{HCl}$ and subsequently washed with deionized water.

\section{Ammonia production}

The bacterial isolate Z1B4 was grown in $5 \mathrm{ml}$ peptone broth at $28^{\circ} \mathrm{C}$. After $24 \mathrm{~h}$ incubation, $0.5 \mathrm{ml} \mathrm{Nes-}$ sler's reagent was added to the bacterial culture and observed for color change from light yellow to dark brown (Cappuccino and Sherman, 1992).

\section{Hydrogen cyanide ( $\mathrm{HCN}$ ) production}

The isolate Z1B4 was streaked on NA supplemented with glycine. Filter paper discs impregnated with $2 \%$ $\mathrm{Na}_{2} \mathrm{CO}_{3}$ prepared in $0.5 \%$ picric acid solution were kept on the inner surface of lids of the Petri plates. The plates were incubated at $28^{\circ} \mathrm{C}$ and observed for color change of the filter paper to orange-brown after $72 \mathrm{~h}$ of incubation (Castric, 1975).

\section{Screening of $Z 1 B 4$ for antagonistic activity against fungal plant pathogens}

The isolate Z1B4 was assessed for its antagonistic activity against fungal plant pathogens by the dual plate assay. The pathogens Fusarium verticillioides 1 (MTCC 3322), Alternaria alternata strain 6663 (MTCC 1362), and Curvularia lunata 716 (MTCC 283) acquired from Microbial Type Culture Collection, Chandigarh, India, were grown on potato dextrose agar at $28^{\circ} \mathrm{C}$ for 5 days. The bacterial culture of Z1B4 grown in NB for $48 \mathrm{~h}$ was 
streaked on yeast malt extract agar plates near the periphery. An agar disc of approximately $6 \mathrm{~mm}$ was taken from the potato dextrose agar plates with the plant pathogen and placed perpendicularly to the bacterial culture on yeast extract agar medium plates. Yeast malt extract plates with the fungal pathogen without bacterial culture served as the control. The plates were incubated at $28^{\circ} \mathrm{C}$ in triplicate. After 7 days of incubation, the percent of reduction in fungal growth was calculated using the following formula: [(control - treated)/control] $\times$ 100 , where control is the diameter of fungal pathogen colony in control plates without bacterium and treated is the diameter of fungal pathogen colony in plates seeded with the bacterium Z1B4.

\section{Z1B4 stress tolerance}

The bacterial strain Z1B4 was grown at different temperatures, $\mathrm{pH}$, salinity, and calcium salt concentrations to determine its stress tolerance, following the method described by Vyas et al. (2009). For temperature effect, the isolate was grown on NA at 10, 15, 20, 25, 30, 35, and $40^{\circ} \mathrm{C}$ for $48 \mathrm{~h} . \mathrm{pH}$ stress was assessed by growing the isolate on NA with $\mathrm{pH} 5,6,7,8$, and 9 at $28^{\circ} \mathrm{C}$. Citrate-phosphate buffer was used to prepare NA with different $\mathrm{pH}$ values. NA medium with $5,7.5$, and $10 \% \mathrm{NaCl}$ was used to study salinity stress. The isolate was also screened for tolerance to calcium salts on nutrient medium plates with 2.5 and $5 \% \mathrm{CaSO}_{4}, 2.5$ and $5 \% \mathrm{CaCl}_{2}$, and 2.5 and $5 \% \mathrm{CaCO}_{3}$.

\section{Generation of rifampicin-resistant mutants of $Z 1 B 4$}

To study whether the isolated endophytic bacterial isolate Z1B4 can enter and proliferate within different parts of the test plants and to determine its endophytic nature, rifampicin-resistant mutants of Z1B4 were generated as described in Gulati et al. (2009). Briefly, the bacterial culture was first grown in NB with $25 \mu \mathrm{g} / \mathrm{ml}$ rifampicin and then transferred to NB with $50 \mu \mathrm{g} / \mathrm{ml}$ rifampicin. Finally, the culture showing growth in NB with $50 \mu \mathrm{g} / \mathrm{ml}$ rifampicin was transferred to NB with $100 \mu \mathrm{g} / \mathrm{ml}$ rifampicin. A loopful of the culture was plated on NA with $100 \mu \mathrm{g} / \mathrm{ml}$ rifampicin. The rif-resistant $\mathrm{mu}-$ tant $\left(\mathrm{Z} 1 \mathrm{~B} 4^{\mathrm{Rif}}\right)$ that showed growth comparable to the wild strain (Z1B4) on rifampicin-supplemented nutrient agar (NA-rif) was selected. The stability of the mutant strain was checked by transferring it five times from NArif to NA and NA-rif plates.

\section{Effect of the bacterial strain $Z 1 B 4$ on plant growth and its recovery from plant parts}

The bacterial isolate Z1B4 and its rifampicin-resistant mutant $\left(Z 1 B 4^{\mathrm{Rif}}\right)$ were assessed for growth enhancement of Pisum sativum (pea) and Zea mays (maize) (Gulati et al., 2009). The seeds were acquired from the local market and were sterilized with $20 \%$ sodium hypochlorite, washed 3-4 times, and immersed for $30 \mathrm{~min}$ in 48-h-old bacterial cultures of Z1B4 and Z1B4 ${ }^{\text {Rif }}$ (OD adjusted to $1.0 \times 10^{9} \mathrm{CFU} / \mathrm{ml}$ ). Earthen pots with $10 \mathrm{~cm}$ diameter were filled with nonsterile garden soil, and two seeds were sown in each pot. Uninoculated control pots were sown with the seeds treated with sterile NB. To determine the initial bacterial count per seed, one seed treated with the bacterial culture was suspended in $9 \mathrm{ml}$ normal saline, and serial dilutions up to $10^{-6}$ were spread plated on NA plates. The experiment was performed in 3 replicates each for three treatments (uninoculated control, Z1B4, and Z1B4 ${ }^{\text {Rif }}$ ) with two seeds per pot/replicate. A randomized block design was used to keep the pots under natural conditions. The experiment on pea was conducted during rabi season from October to November and on maize during kharif season from June to July. Data on root length, shoot length, and dry weight were collected after 45 days of sowing. To determine the total dry weight, the plants were oven dried at $60^{\circ} \mathrm{C}$ for 2 days until constant weight was obtained.

To recover the rifampicin-resistant mutant $P$. fluorescens $\mathrm{Z} 1 \mathrm{~B} 4^{\mathrm{Rif}}$ from the plant parts, the plants were uprooted after 45 days of inoculation, and plant parts were separated. One gram of root, shoot, and leaves samples were macerated separately in sterile pestle and mortar and suspended in $9 \mathrm{ml}$ normal saline. Serial dilutions up to $10^{-7}$ were plated onto NA plates with $100 \mu \mathrm{g} / \mathrm{ml}$ rifampicin. The plates were incubated at $28^{\circ} \mathrm{C}$ for $24-48 \mathrm{~h}$. The bacterial count was expressed as $\mathrm{CFU} / \mathrm{g}$ of the plant sample.

\section{Statistical analysis}

The data were analyzed by one-way ANOVA using the software XLSTAT 2016. Fisher's least significant difference test at $p$ value of 0.05 was used to compare the meanvalues of the treatments. 


\section{Results and discussion}

\section{Isolation and identification of stress-tolerant bacterial endophyte}

Endophytic bacteria are an important component of sustainable agriculture because of their capability to produce a wide range of important metabolites, including plant hormones, enzymes, organic acids, siderophores, $\mathrm{HCN}$, antibiotics, and antifungal metabolites for use in agriculture (Vyas, 2018; Vyas and Kaur, 2019). Bacterial endophytes belonging to Bacillus cereus, Bacillus pumilus, Bacillus thuringiensis, Pseudomonas putida, Pseudomonas sp., and Clavibacter michiganensis have been reported to produce such metabolites (Kumar et al., 2016; Kaur et al., 2017; Vyas and Kaur, 2019). Z. alatum Roxb. is an important medicinal plant of Northeast India, and no reports are available on the isolation of stress-tolerant plant growth-promoting endophytic bacteria from this medicinal plant. Therefore, in the present study, endophytic bacteria were isolated from the leaf samples of $Z$. alatum Roxb. Various biotic and abiotic factors, including temperature, $\mathrm{pH}$, desiccation, salinity, salt concentrations, and plant pathogens, negatively affect the performance of plant growth-promoting bacteria in soil (Vyas et al., 2010). Screening for stress tolerance is one of the important parameters during the selection of bacterial strains for developing microbial inoculants. Therefore, to select stress-tolerant plant growth-promoting and antagonistic bacteria, a salt-tolerant fluorescent green pigment-producing endophytic bacterium was isolated from the leaf tissues of $Z$. alatum Roxb. on $\mathrm{NA}$ with the addition of $2.5 \% \mathrm{NaCl}$. Endophytic bacteria have also been isolated earlier from different medicinal plants; however, no reports are available on the isolation of stress-tolerant endophytic bacteria from $Z$. alatum Roxb. The bacterial isolate was designated Z1B4 and identified on the basis of morphological features, biochemical characteristics, FAME analysis, and 16S rRNA gene sequencing. The isolate was Gram negative, motile, and rod-shaped. The isolate showed positive results for catalase, oxidase, and citrate utilization and negative results for methyl red, Voges Proskauer, indole, and urease. FAME analysis showed that $16: 1 \mathrm{w} 7 \mathrm{c} / 15$ iso $2 \mathrm{OH}(\sim 36 \%), 18: 1 \mathrm{w} 7 \mathrm{c}(\sim 25 \%), 16: 00$ cyclo $(\sim 19 \%)$, and $17: 0$ cyclo $(\sim 11 \%)$ were the major fatty acids detected in the cell wall of Z1B4. The fatty acids 10:0 3OH, $12: 00,12: 02 \mathrm{OH}$, and $12: 03 \mathrm{OH}$ were also detected in the range of $5-8 \%$, while fatty acids $10: 00,14: 00$, and 18:00 were detected in trace amounts. Based on FAME analysis, the isolate Z1B4 showed the highest similarity with $P$. fluorescens. The bacterial isolate was further identified based on 16S rRNA gene sequencing. The BLAST search of the 1372-bp partial 16S rRNA gene sequence of $Z 1 B 4$ showed $99 \%$ identity with $P$. fluorescens strain PSBkS10. The phylogenetic tree based on the $16 \mathrm{~S}$ rRNA gene sequences of $\mathrm{Z1B} 4$ and its nearest neighbors formed two groups, with Z1B4 clustering with different strains of $P$. fluorescens (Fig. 1). The 16S rRNA gene sequence of Z1B4 has been deposited in NCBI GenBank with the accession number MH939241. Endophytic $P$. fluorescens has been isolated from various medicinal plants, including olive root (Gómez-Lama Cabanás et al., 2014), brown sarson (Padder et al., 2016), Miscanthus giganteus leaf (Lally et al., 2017), and Sedum alfredii stem (Chen et al., 2017); however, to the best of our knowledge, there are no reports on the isolation of stress-tolerant endophytic bacteria from $Z$. alatum Roxb.

\section{Screening for plant growth-promoting attributes and stress tolerance}

The salt-tolerant $P$ seudomonas fluorescens Z1B4 was tested for phosphate solubilization, siderophore production, ACC deaminase activity, auxin production, $\mathrm{HCN}$ production, and ammonia production (Table 1). The isolate showed $615 \mu \mathrm{g} / \mathrm{ml}$ tricalcium phosphate solubilization on the fifth day of inoculation in NBRIP broth. The phosphate solubilization ability of Z1B4 compares well with earlier reports on phosphate solubilization by different $P$. fluorescens strains (Oteino et al., 2015; Padder et al., 2016). P. fluorescens strain BIHB740 isolated from seabuckthorn showed tricalcium phosphate solubilization of $768 \mu \mathrm{g} / \mathrm{ml}$ on the fifth day of incubation ( $\mathrm{Gu}-$ lati et al., 2008). Because $P$. fluorescens Z1B4 can solubilize tricalcium phosphate, it can be used as a phosphate solubilizer in calcareous soils where phosphorus is bound with calcium.

Auxin production in the presence of tryptophan is also an important trait for plant growth promotion by bacterial endophytes (Vyas and Kaur, 2019). P. fluorescens $\mathrm{Z1B} 4$ showed auxin production of $17 \mu \mathrm{g} / \mathrm{ml}$ in tryptophan-supplemented medium. The amount of auxin produced by Z1B4 compares well with the recently reported auxin production of $16 \mu \mathrm{g} / \mathrm{ml}$ by an endophytic 


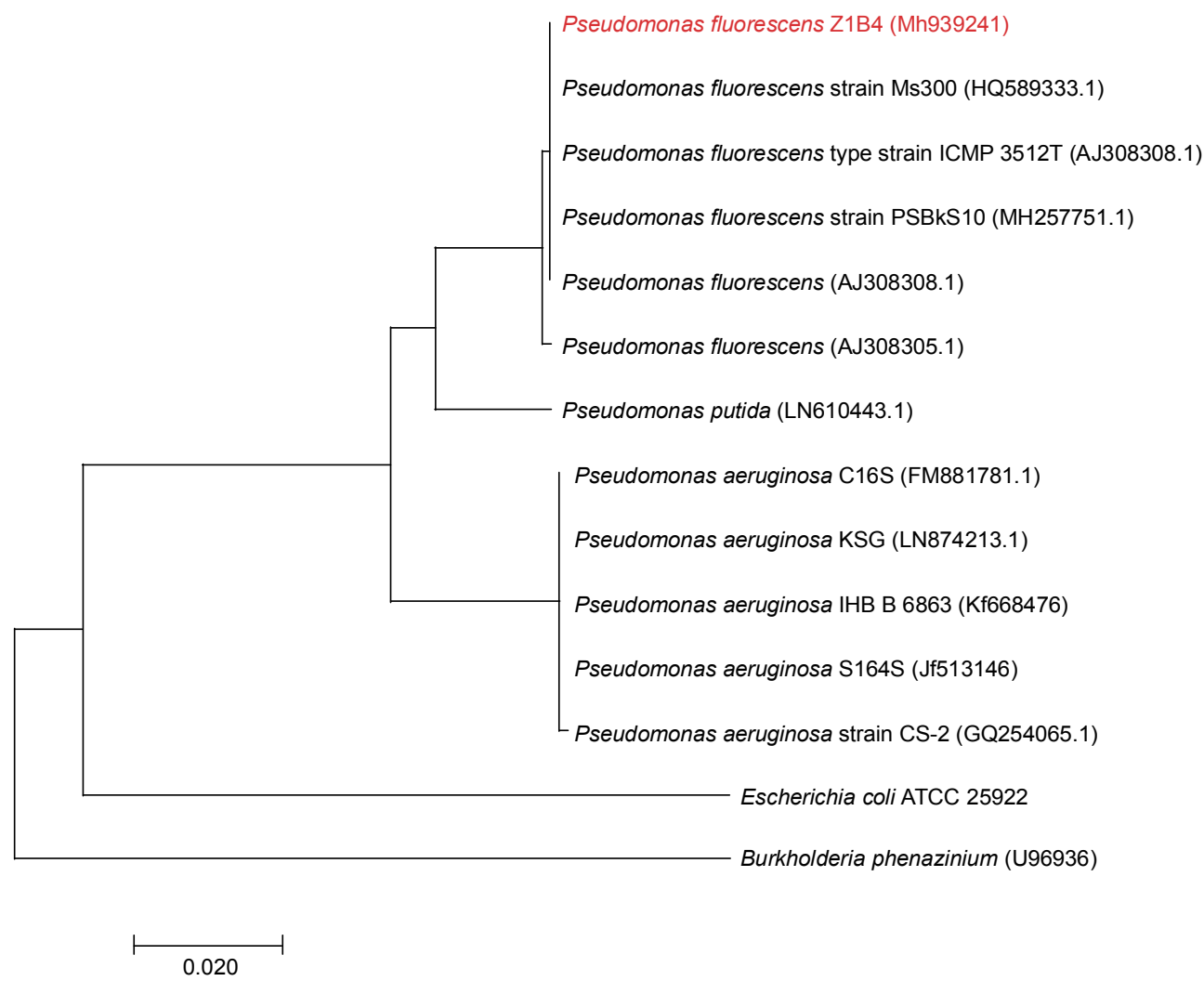

Fig. 1. Phylogenetic tree constructed using the $16 \mathrm{~S}$ rRNA gene sequences of Z1B4 and its nearest neighbors by using the neighbor-joining method

fluorescent Pseudomonas isolated from chickpea seeds (Mukherjee et al., 2020). However, no reports are available on auxin production by $P$. fluorescens from $Z$. alatum Roxb. In addition, the strain Z1B4 showed ACC deaminase activity. Many plant growth-promoting bacteria, including Acinetobacter, Aeromonas, Agrobacterium, Bacillus, Brevibacterium, Enterobacter, Pseudomonas, Pantoea, and Rahnella, produce the enzyme ACC deaminase that helps in enhancing root elongation and plant growth by hydrolyzing ACC from germinating seeds (Gulati et al., 2009; Vyas et al., 2010; Glick, 2014; Kruasuwan and Thamchaipen et al., 2018; Vyas and Kaur, 2019; del Carmen et al., 2020). Many researchers used the ability of bacteria to utilize ACC as a source of nitrogen while screening for ACC-deaminase synthesizing bacteria such as Acinetobacter, Bacillus, Enterobacter, Pseudomonas, and Rahnella (Gulati et al., 2009; Vyas et al., 2010; Glick, 2014; Kaur et al., 2017; Vyas and Kaur, 2019). These bacteria also help in defending plants against various stresses such as flood, drought, salts, heavy metals, and plant pathogens (Karthikeyan et al., 2012; Glick, 2014). Recently, endophytic P. fluo- rescens from Sedum alfredii stem has been reported to show indole-3-acetic acid production, ACC deaminase activity, and siderophore production but did not solubilize phosphate (Chen et al., 2017).

Plant pathogens are responsible for causing huge losses to crop plants worldwide (Savary et al., 2019). The study documented losses associated with 137 pathogens and pests ranging from 19.5 to $41.1 \%$ for maize, 10.1 to $28.1 \%$ for wheat, 24.6 to $40.9 \%$ for rice, 8.1 to $21 \%$ for potato, and 11 to $32.4 \%$ for soybean (Savary et al., 2019). The highest losses were associated frequently with emerging or re-emerging pests and diseases and with food-deficit regions with fast-growing populations (Savary et al., 2019). To control plant pathogens, chemicals are used on a large scale, leading to the emergence of pesticide-resistant pathogens (Chagnon et al., 2015). Therefore, the control of plant diseases using biological methods is a possible alternative to the use of pesticides. In the present study, $P$. fluorescens Z1B4 exhibited antagonism against three fungal pathogens. The strain $21 B 4$ showed $52 \%$ inhibition of $F$. verticillioides, $38.5 \%$ inhibition of $C$. lunata, and $27 \%$ inhibi- 
Table 1. Stress tolerance and plant growth-promoting traits of salt-tolerant Pseudomonas fluorescens Z1B4 from Zanthoxylum alatum Roxb.

\begin{tabular}{|c|c|c|}
\hline \multicolumn{2}{|c|}{ Plant growth-promoting attribute } & Activity/Growth \\
\hline \multicolumn{2}{|c|}{ Tricalcium phosphate solubilization $[\mu \mathrm{g} / \mathrm{ml}]$} & $615.3 \pm 2.96$ \\
\hline \multicolumn{2}{|l|}{ Auxin production $[\mu \mathrm{g} / \mathrm{ml}]$} & $17.0 \pm 1.15$ \\
\hline \multicolumn{2}{|c|}{ Siderophore production [zone, mm] } & $18.7 \pm 1.20$ \\
\hline \multicolumn{2}{|c|}{ Ammonia production } & ++ \\
\hline \multicolumn{2}{|c|}{ 1-aminocyclopropane-1-carboxylate (ACC) deaminase activity } & + \\
\hline \multicolumn{2}{|c|}{ Hydrogen cyanide ( $\mathrm{HCN})$ production } & +++ (strong) \\
\hline \multirow{3}{*}{$\begin{array}{l}\text { Antagonism against fungal } \\
\text { pathogens } \\
\text { (percentage inhibition) }\end{array}$} & Fusarium verticillioides & $52.0 \pm 1.45$ \\
\hline & Curvularia lunata & $38.5 \pm 1.02$ \\
\hline & Alternaria alternata & $27.0 \pm 1.20$ \\
\hline \multirow{7}{*}{$\begin{array}{l}\text { Growth at different } \\
\text { temperatures }\left[{ }^{\circ} \mathrm{C}\right]\end{array}$} & 10 & + \\
\hline & 15 & +++ \\
\hline & 20 & +++ \\
\hline & 25 & +++ \\
\hline & 30 & +++ \\
\hline & 35 & ++ \\
\hline & 40 & + \\
\hline \multirow{5}{*}{ Growth at different $\mathrm{pH}$} & 5 & ++ \\
\hline & 6 & +++ \\
\hline & 7 & +++ \\
\hline & 8 & + \\
\hline & 9 & - \\
\hline \multirow{3}{*}{$\mathrm{NaCl}[\%]$} & 5 & +++ \\
\hline & 7.5 & ++ \\
\hline & 10 & - \\
\hline \multirow{2}{*}{$\mathrm{CaSO}_{4}[\%]$} & 2.5 & +++ \\
\hline & 5 & +++ \\
\hline \multirow{2}{*}{$\mathrm{CaCO}_{3}[\%]$} & 2.5 & +++ \\
\hline & 5 & ++ \\
\hline \multirow{2}{*}{$\mathrm{CaCl}_{2}[\%]$} & 2.5 & ++ \\
\hline & 5 & - \\
\hline
\end{tabular}

Values represent the mean of three replicates \pm standard error of the mean $\left(\mathrm{SE}_{\text {mean }}\right) ;(+++)-$ strong activity/luxuriant growth, $(++)$ - moderate activity/good growth, $(+)-$ weak activity/ poor growth, (-) - no activity/no growth

tion of $A$. alternata (Table 1). The antagonistic activity of $P$. fluorescens Z1B4 was higher than that of the endophytic fluorescent Pseudomonas sp. strain isolated from the medicinal plant $T$. cordifolia, which showed 38\% inhibition of $A$. alternata, $25 \%$ inhibition of $C$. lunata, and $24 \%$ inhibition of $F$. verticillioides (Kaur et al., 2017). Likewise, $P$. fluorescens isolated from the nodules of faba beans showed 51\% growth inhibition of Fusarium solani (Bahroun et al., 2018). The high antagonistic activity of the bacterial strain Z1B4 can be correlated with the production of $\mathrm{HCN}$ and siderophores as this strain exhibited HCN and siderophore production (Table 1).

Selecting stress-tolerant bacterial strains is crucial for their consistent field performance when applied as 
Table 2. Growth promotion of pea (Pisum sativum) and maize (Zea mays) by stress-tolerant endophyte Pseudomonas fluorescens Z1B4 from Zanthoxylum alatum Roxb.

\begin{tabular}{c|l|c|c|c|c}
\hline \multirow{2}{*}{ Plant } & \multirow{2}{*}{ Parameter } & \multicolumn{3}{|c|}{ Isolate } & \multirow{2}{*}{$\begin{array}{c}\text { Fisher's LSD } \\
(P=0.05)\end{array}$} \\
\cline { 3 - 6 } & & control & Z1B4 & Z1B4 ${ }^{\text {Rif }}$ & 1.9 \\
\hline \multirow{4}{*}{ Maize } & root length $[\mathrm{cm}]$ & $16.5^{\mathrm{a}}$ & $21.5^{\mathrm{b}}(30.3)$ & $22.0^{\mathrm{b}}(33.3)$ & 2.3 \\
\cline { 2 - 6 } & shoot length $[\mathrm{cm}]$ & $32.3^{\mathrm{a}}$ & $41.5^{\mathrm{b}}(28.5)$ & $40.2^{\mathrm{b}}(24.4)$ & 0.05 \\
\cline { 2 - 6 } & total dry weight $[\mathrm{g}]$ & $0.20^{\mathrm{a}}$ & $0.29^{\mathrm{b}}(45.0)$ & $0.27^{\mathrm{b}}(35.0)$ & 1.9 \\
\hline \multirow{3}{*}{ Pea } & root length [cm] & $12.3^{\mathrm{a}}$ & $15.3^{\mathrm{b}}(24.4)$ & $14.8^{\mathrm{b}}(20.3)$ & 2.2 \\
\cline { 2 - 6 } & shoot length $[\mathrm{cm}]$ & $19.5^{\mathrm{a}}$ & $26.3^{\mathrm{b}}(34.9)$ & $27.0^{\mathrm{b}}(38.5)$ & 0.04 \\
\cline { 2 - 6 } & total dry weight $[\mathrm{g}]$ & $0.17^{\mathrm{a}}$ & $0.24^{\mathrm{b}}(41.2)$ & $0.23^{\mathrm{b}}(35.3)$ & \\
\hline
\end{tabular}

Values represent the mean of three replicates; values in brackets represent percent (\%) increase over uninoculated control; values with different letters in each row are significantly different from one another at $P \leq 0.05$

microbial inoculants (Vyas and Kaur, 2019). To date, only a few studies have used the stress tolerance criterion along with other traits in the development of microbial inoculants (Vyas et al., 2009; Molina-Romero et al., 2017; Kaur et al., 2018; Vyas and Kaur, 2019). Therefore, in the present study, $P$. fluorescens Z1B4 was tested for its tolerance to different $\mathrm{pH}$, temperature, calcium salts, and $\mathrm{NaCl}$ (Table 1). Among the tested $\mathrm{pH}$, Z1B4 could grow on a medium with $\mathrm{pH}$ value up to 8 and showed no growth at $\mathrm{pH}$ 9.0. Among the different temperatures $\left(10,15,20,25,30,35\right.$ and $\left.40^{\circ} \mathrm{C}\right)$, the strain Z1B4 showed good growth in the temperature range of 15 to $35^{\circ} \mathrm{C}$ but showed poor growth at 10 and $40^{\circ} \mathrm{C}$. Z1B4 could also grow at concentrations upto $7.5 \% \mathrm{NaCl}$, $5 \% \mathrm{CaSO}_{4}, 5 \% \mathrm{CaCO}_{3}$, and $2.5 \% \mathrm{CaCl}_{2}$ (Table 1). The results agree with those of an earlier study in which P. fluorescens strain BIHB740 isolated from seabuckthorn exhibited tolerance to temperature, $\mathrm{pH}, \mathrm{NaCl}$, and calcium salts (Vyas et al., 2009). Abiotic stress-tolerant $P$. fluorescens, $P$. aeruginosa, $P$. putida, $P$. plecoglossicida, $P$. mosselli, and Pseudomonas sp. isolated from groundnut, pigeon pea, and sorghumcould tolerate temperature up to $45^{\circ} \mathrm{C}$ and salinity up to $1 \mathrm{M} \mathrm{NaCl}$ (Ashwitha et al., 2013). However, no literature data are available on the stress-tolerant endophytic $P$. fluorescens associated with $Z$. alatum Roxb.

\section{Effect of P. fluorescens Z1B4 on plant growth and its recovery from plant parts}

A signi cant increase in the growth of maize and pea test plants was observed following inoculation with $P$. fluorescens Z1B4as compared to uninoculated control under controlled environmental conditions (Table 2). An increase of $24.4,34.9$, and $41.2 \%$ in root length, shoot length, and dry weight, respectively, was observed in pea plants inoculated with Z1B4. Compared to the uninoculated control, the increase in root length, shoot length, and dry weight of maize on inoculation with Z1B4 was $30.3,28.5$, and $45 \%$, respectively (Table 2). Inoculation of endophytic $P$. fluorescens strains from Miscanthus giganteus leaves showed similar growth-promoting effects on P. sativum (Oteino et al., 2015). Likewise, maize plants inoculated with endophytic Pseudomonas sp. from the medicinal plant T.cordifolia exhibited 33, 31 , and $38 \%$ increase in root length, shoot length, and dry weight, respectively, over uninoculated control (Vyas and Kaur, 2017). However, the increase in dry weight noted in the present study following the inoculation of Z1B4 was much higher than the increase of $23.97 \%$ in total dry weight over uninoculated control following the inoculation of an endophytic strain of $P$. fluorescens in $B$. napus (Lally et al., 2017).

The outcome and success of a plant growth-promoting microbial inoculant depend on its ability to proliferate in the target habitat (Vyas et al., 2010; Schreiter et al., 2018). Therefore, in the present study, the establishment of $P$. fluorescens Z1B4 in root, shoot, and leaves of the test plants was studied by generating rifampicin-resistant mutants of Z1B4 designated as $Z 1 B 4^{\text {Rif }}$. The initial count of $Z 1 B 4^{\text {Rif }}$ per seed of maize and pea was $6.3 \times 10^{5}$ and $2.5 \times 10^{6}$ cells, respectively. The bacterial count recovered from the root, shoot, and leaves of pea was $7.8 \times 10^{7}, 5.3 \times 10^{7}$, and $3.3 \times 10^{8}$ cells, respecti- 
Table 3. Recovery of rifampicin-resistant mutant of Pseudomonas fluorescens Z1B4 after 45 days inoculation

\begin{tabular}{c|c|c}
\hline Plant & Part & CFU/g plant sample \\
\hline \multirow{4}{*}{ Pisum sativum } & root & $7.8 \times 10^{7}(7.89 \pm 0.15)$ \\
\cline { 2 - 3 } & shoot & $5.3 \times 10^{7}(7.72 \pm 0.20)$ \\
\cline { 2 - 3 } & leaf & $3.3 \times 10^{8}(8.52 \pm 0.05)$ \\
\hline \multirow{4}{*}{ Zea mays } & root & $3.5 \times 10^{7}(7.54 \pm 0.05)$ \\
\cline { 2 - 3 } & shoot & $6.5 \times 10^{6}(6.98 \pm 0.10)$ \\
\cline { 2 - 3 } & leaf & $9.3 \times 10^{7}(7.97 \pm 0.25)$ \\
\hline
\end{tabular}

Values represent the mean of three replicates; initial count of the bacterium per seed of pea and maize was $6.3 \times 10^{5}$ and $2.5 \times 10^{6}$, respectively; values in parentheses indicate $\log _{10} \mathrm{CFU} / \mathrm{g}$ sample

pectively, and that from maize was $3.5 \times 10^{7}, 6.5 \times 10^{6}$, and $9.3 \times 10^{7}$ cells, respectively. The bacterial isolate $\mathrm{Z1B} 4^{\text {Rif }}$ was successfully recovered from the root, shoot, and leaf samples of both maize and pea plants after 45 days of inoculation, indicating that the isolated species was an endophytic bacterium (Table 3). A significant increase in root length, shoot length, and dry matter of pea and maize over uninoculated control was recorded after inoculation with the mutant strain $\mathrm{Z1B} 4^{\text {Rif }}$ (Table 2). The increase in plant growth by the mutant strain Z1B4 ${ }^{\text {Rif }}$ was statistically not different from that of the wild-type strain Z1B4 (Table 2). Similar results were obtained in a study where rhizosphere competence of $P$. fluorescens was studied by generating rifampicinresistant mutants (Nautiyal, 1997). Similarly, rifampicinresistant mutant of plant growth-promoting Acinetobacter rhizosphaerae exhibited root colonization and growth promotion in pea (Gulati et al., 2009). Plant growth promotion observed with the wild-type strain of Acinetobacter rhizosphaerae was significantly not different from that of its mutant strain as also observed in the present study. Likewise, rhizosphere competence of cold-tolerant Rahnella sp. isolated from seabuckthorn was studied by generating rifampicin-resistant mutants (Vyas et al., 2010). The result indicated that the P. fluorescens strain $\mathrm{Z1B} 4$ has the potential to be used as a plant growth-promoting microbial inoculant.

\section{Conclusions}

Endophytic bacteria are important constituents of sustainable agriculture in stressed environments as they can synthesize a wide range of metabolites and can also help plants to grow under environmental stress condi- tions. However, the effectiveness of the microbial inoculants is negatively affected by various abiotic and biotic stresses, including temperature, $\mathrm{pH}$, desiccation, salinity, salts, and plant pathogens. Therefore, microorganisms should also be screened for tolerance against various stress conditions during the development of bioinoculants for agriculture. In the present study, endophytic $P$. fluorescens Z1B4 exhibited multifarious plant growth-promoting traits and stress tolerance and led to improved growth of pea and maize plants, which is essential for enhancing growth of plants for sustainable agriculture. The strain Z1B4 also showed strong antagonistic activity against fungal pathogens, which can correlated with its ability to produce $\mathrm{HCN}$ and siderophores. The present study provided a "fail-safe" screening method for the development of microbial inoculants for sustainable agriculture. The results of the present study indicated the potential of the strain $P$. fluorescens $\mathrm{Z1B} 4$ for use as a microbial inoculant for consistent field performance. To the best of our knowledge, stress-tolerant plant growth-promoting endophytic $P$. fluorescens from the medicinal plant Z.alatum Roxb. is reported for the first time.

\section{Acknowledgments}

The authors acknowledge Lovely Professional University for providing the financial support to conduct the research studies and Punjab Agricultural University, Punjab, for providing the necessary facilities.

\section{References}

Annappan U., Rajkishore V.B., Ramalingam R. (2015) A review on Zanthoxylum alatumRoxb. Res. J. Pharmacognosy Phytochem. 7: 223. doi: 10.5958/0975-4385.2015.00034.5

Ashwitha K., Rangeshwaran R., Vajid N.V., Sivakumar G., Jalali S.K., Rajalaksmi K., Manjunath H. (2013) Characterization of abiotic stress tolerant Pseudomonas sp. occurring in Indian soils. J. Biol. Control. 27: 45-48. https:// doi.org/10.18311/jbc/2013/3264

Bahroun A., Jousset A., Mhamdi R., Mrabet M., Mhadhbi H. (2018) Anti-fungal activity of bacterial endophytes associated with legumes against Fusarium solani: assessment of fungi soil suppressiveness and plant protection induction. Appl. Soil Ecol. 124: 131-140. https://doi.org/ 10.1016/j.apsoil.2017.10.025

Castric P.A. (1975) Hydrogen cyanide a secondary metabolite of Pseudomonas aeruginosa. Can. J. Microbiol. 21: 613-618. https://doi.org/10.1139/m75-088

Cappuccino J.C., Sherman N. (1992) Microbiology: a laboratory manual. Benjamin/Cummings Publishing Co., New York: 125-179. https://doi.org/10.4236/as.2014.510085 
Chagnon M., Kreutzweiser D., Mitchell E.A., Morrissey C.A., Noome D.A., Van der Sluijs J.P. (2015) Risks of large-scale use of systemic insecticides to ecosystem functioning and services. Environ. Sci. Pollut. Res. 22(1): 119-134. https:// doi.org/10.1007/s11356-014-3277-x

Chen B., Luo S., Wu Y., Ye J., Wang Q., Xu X., Pan F., Khan K.Y., Feng Y., Yang X. (2017) The effects of the endophytic bacterium Pseudomonas fluorescens Sasm05 and IAA on the plant growth and cadmium of sedum alfredii Hance. Front. Microbiol. 8: 2538. https://doi.org/10.3389/ fmicb.2017.02538

del Carmen Orozco-Mosqueda M., Glick B.R., Santoyo G. (2020) ACC deaminase in plant growth-promoting bacteria (PGPB): an efficient mechanism to counter salt stress in crops. Microbiol. Res. 235: 126439.

Fadiji A.E., Babalola O.O. (2020) Exploring the potentialities of beneficial endophytes for improved plant growth. Saudi J. Biol. Sci. 27(12): 3622-3633. https://doi.org/10.1016/ j.sjbs.2020.08.002

Ghosh R., Barman S., Khatun J., Mandal N.C. (2016) Biological control of Alternaria alternata causing leaf spot disease of Aloe vera using two strains of rhizobacteria. Biol. Control 97: 102-108. https://doi.org/10.1016/j.biocontrol. 2016.03.001

Glick B.R. (2014) Bacteria with ACC deaminase can promote plant growth and help to feed the world. Microbiol. Res. 169:30-39. https://doi.org/10.1016/j.micres.2013.09.009

Gómez-Lama Cabanás C., Schilirò E., Valverde-Corredor A., Mercado-Blanco J. (2014) The biocontrol endophytic bacterium Pseudomonas fluorescens PICF7 induces systemic defense responses in aerial tissues upon colonization of olive roots. Front. Microbiol. 5: 427. https://doi.org/ 10.3389/fmicb.2014.00427

Gulati A., Rahi P., Vyas P. (2008) Characterization of phosphate solubilizing fluorescent pseudomonads from rhizosphere of seabuckthorn growing in cold deserts of Himalayas. Curr. Microbiol. 56: 73-79. https://doi.org/10.1007/ s00284-007-9042-3

Gulati A., Sharma N., Vyas P., Sood S., Rahi P., Pathania V., Prasad R. (2010) Organic acid production and plant growth promotion as a function of phosphate solubilization by Acinetobacter rhizosphaerae from the cold deserts of the trans-Himalayas. Arch. Microbiol. 192: 975-983. https:// doi.org/10.1007/s00203-010-0615-3

Gulati A., Vyas P., Rahi P., Kasana R.C. (2009) Plant growth promoting and rhizosphere competent Acinetobacter rhizosphaerae strain BIHB 723 from the cold deserts of Himalayas. Curr. Microbiol. 58: 371-377. https://doi.org/ 10.1007/s00284-008-9339-x

Karthikeyan B., Joe M.M., Islam M.R., Sa T. (2012) ACC deaminase containing diazotrophic endophytic bacteria ameliorate salt stress in Catharanthus roseus through reduced ethylene levels and induction of antioxidative defense systems. Symbiosis 56: 77-86. https://doi.org/10.1007/ s13199-012-0162-6

Kaur R., Devi M.A., Vyas P. (2017) Endophytic Pseudomonas sp. TCA1 from Tinospora cordifolia stem with antagonistic and plant growth-promoting potential. Res. J. Pharmacy Technol. 10(2): 456-460. https://doi.org/10.5958/0974360X.2017.00092.0

Kaur A., Devi S.R., Vyas P. (2018) Stress-tolerant antagonistic plant growth-promoting rhizobacteria from Zea mays. J. Plant Prot. Res. 58: 115-123. https://doi.org/10.24425/ 119127

Kumar A., Singh R., Yadav A., Giri D.D., Singh P.K., Pandey K.D. (2016) Isolation and characterization of bacterial endophytes of Curcuma longa L. 3 Biotech 6(1): 60-68. https://doi.org/10.1007/s13205-016-0393-y

Krieg N.R., Holt J.G. (1984) Bergey's Manual of Systematic Bacteriology. vol. 1. Williams and Willkins, Baltimore: 964.

Kruasuwan W., Thamchaipenet A. (2018) 1-Aminocyclopropane-1-carboxylate $(A C C)$ deaminase-producing endophytic diazotrophic Enterobactersp. EN-21 modulates salt-stress response in sugarcane. J. Plant Growth Regul. 37(3): 849-858. https://doi.org/10.1007/s00344-018-9780-4

Lal M., Kumar S., Ali M., Khan A., Singh V., Murti S. (2013) Host range, susceptibility period of Curvularialunata causing leaf spot of black gram and germplasm screening. Agriways 1: 142-146.

Lally R.D., Galbally P., Moreira A.S., Spink J., Ryan D., Germaine K.J., Dowling D.N. (2017) Application of endophytic Pseudomonas fluorescens and a bacterial consortium to Brassica napus can increase plant height and biomass under greenhouse and field conditions. Front. Plant Sci. 8: 2193. https://doi.org/10.3389/fpls.2017.02193

Lata R., Chowdhury S., Gond S.K., White Jr J.F. (2018) Induction of abiotic stress tolerance in plants by endophytic microbes. Lett. Appl. Microbiol. 66(4): 268-276.

Liu F., Yuan Z., Zhang X., Zhang G., Xie B. (2017) Characteristics and diversity of endophytic bacteria in moso bamboo (Phyllostachys edulis) based on 165 rDNA sequencing. Arch. Microbiol. 199(9): 1259-1266.

Loper J.E., Schroth M.N. (1986) Influence of bacterial sources of indole-3-acetic acid on root elongation of sugarbeet. Phytopathol. 76: 386-389.

Mao A.A., Hynniewta T.M. (2000) Floristic diversity of North East India. J. Assam Science Soc. 41: 255-266.

Molina-Romero D., Baez A., Quintero-Hernández V., Castañeda-Lucio M., Fuentes-Ramírez L.E., del RocíoBustillosCristales M., Rodríguez-Andrade O., Morales-García Y.E., Munive A., Muñoz-Rojas J. (2017) Compatible bacterial mixture, tolerant to desiccation, improves maize plant growth. Plos One 12: e0187913. https://doi.org/10.1371/ journal.pone.0187913

Mohamad O.A., Li L., Ma J.B., Hatab S., Xu L., Guo J.W., Rasulov B.A., Liu Y.H., Hedlund B.P., Li W.J. (2018) Evaluation of the antimicrobial activity of endophytic bacterial populations from Chinese traditional medicinal plant licorice and characterization of the bioactive secondary metabolites produced by Bacillus atrophaeus against Verticillium dahliae. Front. Microbiol. 9: 924. https://doi.org/ 10.3389/fmicb.2018.00924

Mukherjee A., Singh B.K., Verma J.P. (2020) Harnessing chickpea (Cicer arietinum L.) seed endophytes for enhan- 
cing plant growth attributes and bio-controlling against Fusarium sp. Microbiol. Res. 237: 126469. https://doi.org/ 10.1016/j.micres.2020.126469

Nautiyal C.S. (1997) A method for selection and characterization of rhizosphere-competent bacteria of chickpea. Curr. Microbiol. 34: 12-17. https://doi.org/10.1007/ s002849900136

Nautiyal C.S. (1999) An efficient microbiological growth medium for screening phosphate-solubilizing microorganisms. FEMS Microbiol. Lett. 170: 265-270. https://doi.org/ 10.1111/j.1574-6968.1999.tb13383.x

Oteino N., Lally R.D., Kiwanuka S., Lloyd A., Ryan D., Germaine K.J., Dowlin D.N. (2015) Plant growth promotion induced by phosphate solubilizing endophytic Pseudomonas isolates. Front. Microbiol. 6: 745. https://doi.org/ 10.3389/fmicb.2015.00745

Padder S.A., Dar G.H., Mohiddin F.A., Shah M.D. (2016) Characterization and plant growth promoting aspects of a novel phosphate solubilizing brown sarson endophyte Pseudomonas fluorescens strain smppsap5 isolated from Northern Himalayas of India. J. Pure App. Microbiol. 10: 2003-2018.

Pageni B.B., Lupwayi N.Z., Akter Z., Larney F.J., Kawchuk L.M., Gan Y. (2014) Plant growth-promoting and phytopathogen-antagonistic properties of bacterial endophytes from potato (Solanum tuberosum L.) cropping systems. Can. J. Plant Sci. 94: 835-844.

Parnell J.J., Berka R., Young H.A., Sturino J.M., Kang Y., Barnhart D.M., DiLeo M.V. (2016) From the lab to the farm: an industrial perspective of plant beneficial microorganisms. Front. Plant Sci. 7: 1110. https://doi.org/10.3389/ fpls.2016.01110

Porter S.S., Bantay R., Friel C.A., Garoutte A., Gdanetz K., Ibarreta K., Moore B.M., Shetty P., Siler E., Friesen M.L. (2020) Beneficial microbes ameliorate abiotic and biotic sources of stress on plants. Funct. Ecol. 34(10): 2075-2086. https://doi.org/10.1111/1365-2435.13499

Rustamova N., Wubulikasimu A., Mukhamedov N., Gao Y., Egamberdieva D., Yili A. (2020) Endophytic bacteria associated with medicinal plant Vernonia anthelmintica: diversity and characterization. Curr. Microbiol. 77: 1457-1465. https://doi.org/10.1007/s00284-020-01924-5

Sasser M., Wichman M.D. (1991) Identi cation of microorganisms through use of gas chromatography and highperformance liquid chromatography. [in:] Manual of Clinical Microbiology, 5th ed. American Society for Microbiology, Washington, DC.

Savary S., Willocquet L., Pethybridge S.J., Esker P., McRoberts N., Nelson A. (2019) The global burden of pathogens and pests on major food crops. Nat. Ecol. Evol. 3(3): 430-439. https://doi.org/10.1038/s41559-018-0793-y
Schreiter S., Babin D., Smalla K., Grosch R. (2018) Rhizosphere competence and biocontrol effect of Pseudomonas sp. RU47 independent from plant species and soil type at the field scale. Front. Microbiol. 9: 97. https://doi.org/ 10.3389/fmicb.2018.00097

Schwyn B., Neilands J.B. (1987) Universal chemical assay for the detection and determination of siderophores. Anal. Biochem. 160: 45-56. https://doi.org/10.1016/0003-2697 (87)90612-9

Sharan A., Shikha D.N.S., Gaur R. (2008) Xanthomonas campestris, a novel stress tolerant, phosphate-solubilizing bacterial strain from saline-alkali soils. W. J. Microbiol. Biotechnol. 24: 753-759. https://doi.org/10.1007/s11274-0079535-z

Tripathi R.S., Roy A., Kushwaha D., Lalnunmawia F., Lalnundanga L.H., Lalnunzira C., Roy P.S. (2016) Perspectives of forest biodiversity conservation in Northeast India. J. Biodiversity, Bioprospecting Develop. 3(2): 1-9.

Venkataraman K., Sivaperuman C. (2018) Biodiversity hotspots in India. In: Indian Hotspots. Springer, Singapore: 1-27.

Vyas P. (2018) Endophytic microorganisms as bio-inoculants for sustainable agriculture [in:] Microbial bioprospecting for sustainable development. Vol 1: 41-60. ISBN: 978-98113-0053-0

Vyas P., Joshi R., Sharma K.C., Rahi P., Gulati A., Gulati Arvind (2010) Cold-adapted and rhizosphere-competent strain of Rahnella sp. with broad-spectrum plant growthpromotion potential. J. Microbiol. Biotechnol. 20: 1724-1734. https://doi.org/10.4014/jmb.1007.07030

Vyas P., Kaur R. (2017) Plant growth-promoting and antagonistic endophytic bacteria from the medicinal plant Tinospora cordifolia stem. Int. J. Res.Pharm. Sci. 8: 189-193

Vyas P., Kaur A. (2018) Stress-tolerant antagonistic rhizobacteria isolated from the medicinal plant Tinospora cordifolia. Biotechnologia 99: 129-136. https://doi.org/10.5114/bta. 2018.75656

Vyas P., Kaur R. (2019) Culturable stress-tolerant plant growth-promoting bacterial endophytes associated with Adhatodavasica. J. Soil Sci. Plant Nutr. 19: 290-298. https://doi.org/10.1007/s42729-019-00028-9

Vyas P., Rahi P., Gulati A. (2009) Stress tolerance and genetic variability of phosphate-solubilizing fluorescent Pseudomonas from the cold desert of the trans-Himalayas. Microbial. Ecol. 8: 425-434. https://doi.org/10.1007/s00248009-9511-2

Yuan Z.S., Liu F., Zhang G.F. (2015) Isolation of culturable endophytic bacteria from Moso bamboo (Phyllostachys edulis) and $16 S$ rDNA diversity analysis. Arch. Biol. Sci. 67(3): 1001-1008. https://doi.org/10.2298/ABS 141212063Y 